\title{
EDUKASI 'GERAKAN SISWA ANTI NARKOBA' (GESWANA) ERA DESRUPSI 4.0 DI SMP WAHID HASYIM MALANG
}

\author{
Isvi Rahmatul Mustafa ${ }^{1}$, Muhammad Bastomi Abdillah ${ }^{2}$, Novi Rani Winata ${ }^{3}$, Riki Pratama ${ }^{4}$, \\ Rosi Isnanda ${ }^{5}$, Teguh Dias Arestu Putra ${ }^{6}$, Wahyu Djoko Sulistyo*7 \\ 1,2,3,4,5,6,7 Jurusan Sejarah, Fakultas Ilmu Sosial,Universitas Negeri Malang \\ Jl. Semarang No.5 Kota Malang 65145 \\ *E-mail: wahyu.djoko.fis@um.ac.id
}

\begin{abstract}
In the news on JawaPos.com explained that drug abuse in Malang City, $60 \%$ are students and students need extra attention from the government. This is in line with the words of the Coordinating Minister for Politics, Law and Security, that drugs are the biggest threat to the Indonesian nation. The purpose of the Anti-Narcotics Student Movement (GESWANA) activity was held at the Wahid Hayim Middle School in Malang to increase students' knowledge as a teenager about Narcotics and challenges in Industrial Era 4.0 to deal with it. Data collection is done through observing the enthusiasm of students in participating in activities, but also by conducting post-activity evaluations. The activity was held for all class VII, VIII, and IX students of Wahid Hasyim Malang City. Furthermore the results show that the enthusiasm of students in participating in the socialization activities is very high, in theory they have known Narcotics in general and additional information to find out the types of the latest Narcotics inventions.
\end{abstract}

Keywords-Drugs, Industry 4.0, Wahid Hayim Middle School

\section{Abstrak}

Dalam berita di JawaPos.com dijelaskan bahwa penyalahgunaan narkoba di Kota Malang, 60\% merupakan para pelajar dan mahasiswa sehingga perlu perhatian ekstra dari pemerintah. Hal tersebut senada dengan ucapan Menteri Kordinator Bidang Politik, Hukum dan Keamanan, bahwa narkoba merupakan ancaman terbesar bagi bangsa Indonesia. Tujuan diadakan kegiatan Gerakan Siswa Anti Narkoba (GESWANA) di SMP Wahid Hayim Kota Malang tersebut untuk menambah pengetahuan siswa sejak remaja tentang Narkotika dan tantangan di Era Industri 4.0 untuk menghadapinya. Pengumpulan data dilakukan melalui pengamatan terhadap antusias siswa dalam mengikuti kegiatan, selain itu juga dengan melakukan evaluasi pasca kegiatan. diadakan kegiatan tersebut untuk seluruh angkatan kelas VII, VIII, dan IX SMP Wahid Hasyim Kota Malang. Selanjutnya hasilnya menunjukkan bahwa antusiasme siswa dalam mengikuti kegiatan sosialisasi tersebut sangat tinggi, secara teori mereka sudah mengetaui Narkotika secara umum dan tambahan informasi untuk mengetahui jenis-jenis penemuan Narkotika terbaru.

Kata kunci-Geswana, Industri 4.0, SMP Wahid Hayim

\section{PENDAHULUAN}

Kota Malang merupakan salah satu daerah di provinsi Jawa Timur yang secara geografis terletak pada ketinggian 440-667 meter diatas permukaan air laut. Letaknya berada di 112,06'112,07' Bujur Timur dan 7,06'-8,02' Lintang Selatan. Dilihat dari kondisi iklimnya, Kota Malang tercatata suhu udara sekitar antara $22,7^{\prime} \mathrm{C}-25,1^{\prime} \mathrm{C}$ sedangkan suhu maksimum mencapai 32,7' $\mathrm{C}$ dan suhu minimum 18,4'C. Secara Geologi Keadaan tanah di Wilayah Kota Malaflng bagian selatan termasuk dataran tinggi yang cukup luas untuk industry, bagian utara termasuk dataran tinggi yang subur untuk pertanian, bagia timur dataran yang kurang subur dan bagian barat merupakan dataran tinggi yang amat luas menjadi daerah pendidikan untuk di Kota Malang [1]. 
Kota Malang merupakan kota yang besar di kawasa Jawa Timur, sehingga dalam hal peredaran narkoba menjadi sasaran bagi para pengedarnya. Di JawaPos.com terbitan tanggal 13 Maret 2018 dijelaskan bahwa penyalahgunaan Narkoba di Malang harus menjadi perhatian khusus dan ekstra dari Pemerintah Kota Malang. Hal ini bahwa sekitar $60 \%$ kasus yang berada di Kota Malang didominasi oleh kalangan pelajar dan mahasiswa. Data yang diperoleh dari Polres Kota Malang selama Januari-Februari 2018 setidaknya sudah ada 36 Kasus terkait Narkoba. Dari kasus tersebut terdapat 45 tersangka dan yang lebih miris lagi bahwa dari 45 tersangka, $60 \%$ merupakan pelajar [2].

Dalam artikel bnn.go.id terbitan 29 Maret 2019 Menteri Koordinator Bidang Politik, Hukum dan Keamanan Wiranto menegaskan bahwa narkoba merupakan ancaman terbesar bangsa Indonesia saat ini. Disampaikan bahwa 1 hari 30 orang rakyat kita yang mati terkena Narkoba. Hal ini menjadikan Narkotika harus mendapatkan perhatian khusus dari pemerintah Indonesia untuk menangani secara ekstra dan penuh terhadap permasalahan yang satu ini. Menko Polhukam Wiranto tersebut menyampaikan saat Seminar Nasional dengan tema Narkotika di UIN Syarif Hidayatullah Jakarta [3].

Dari pemaparan yang telah disampaikan bahwa di Indonesia sangat genting dengan masalah Narkotika. Lebih merujuk lagi pada Kota Malang, dari artikel yang didapatkan data dari polres Kota Malang bahwa Narkoba telah merasuk kedalam kalangan remaja. Remaja menjadi sasaran utama Narkota dan menjadikan perhatian khusus untuk menangani permasalahan yang serius ini. Pelu adanya upaya-upaya yang dilakukan pemerintah dan berbagai pihak. Sebagai mahasiswa yang berperan dalam hal perubahan dan kebermanfaatan di kehidupan masyarakat. Maka dilaksanakan sosialisasi tentang Narkoba atau Gerakan Siswa Anti Narkoba (GESWANA) di SMP Wahid Hayim Kota Malang dengan sasaran seluruh siswa dari kelas VII, VIII, dan IX. Kegitan pengabdian ini dalam rangka implementasi kegiatan praksis sosial untuk dapt menggugah rasa kepekaan sosial mahasiswa [4] . Kegiatan ini memiliki tujuan yaitu untuk mengenalkan pola kehidupan yang sehat bagi para siswa sebagai generasi muda, karena penting bagi mereka pengetahuan ini[5]. Selain itu kegiatan ini juga dapat memberi pemahaman dan memberikan wawasan yang luas serta pertahanan diri sendiri di Era Industri 4.0 ini dalam menghadapi Narkotika tersebut.

\section{METODE}

Metode yang digunakan adalah observasi langsung dan sosialisasi disekolah sasaran. Kegiatan sosialisasi Gerakan Siswa Anti Narkoba (GESWANA) di adakan di SMP Wahid Hasyim Kota Malang pada Hari Jumat, 29 Maret 2019 dengan peserta yaitu seluruh siswa SMP Wahid Hayim dengan total peserta setidaknya 300 anak dari kelas VII. VIII, IX. Kegiatan ini dibantu oleh pihak sekolah dan bantuan dari teman-teman kelompok serta dari UKM GERMAN UM. Perlengkapan berupa sound system dan LCD sudah disediakan disekolahnya. Untuk materi berupa video tentang era industry 4.0, dan berupa materi narkotika oleh kelompok dan langsung dari UKM GERMAN dalam bentuk Microsoft Power Point. Kegiatan tersebut berlangsung mulai jam 07.30 WIB s.d 09.30 WIB. Jalanya kegiatan sosialisasi dilakukan melalui tiga tahap, yang pertama adalah pemutaran video mengenai kenakalan remaja, sesi kedua sosialisasi materi globalisasi dan sesi yang terakhir sosialisasi mengenai bahaya narkoba.

\section{HASIL DAN PEMBAHASAN}

\subsection{Pentingnya Wawasan Pengetahuan Tentang Narkoba}

Data Badan Narkotika Nasional (BNN) yang terbaru menjelaskan bahwa dari sekian pecandu narkoba yang ada di Indonesia, sekitar $24 \%$ merupakan para pelajar yang keblinger dan lepas kendali hingga menjadi pecandu [6]. Kerentanan para pelajar yang masih dalam fase remaja menjadikan banyak yang terjerumus kedalam permasalahan ini. Fase remaja yang masih dalam proses mencari jati diri dan rasa ingin tahu yang besar terhadap sesuatu yang menjadi faktor yang utama yang mendorong pelajar terseret oleh permasalahan ini, selain itu remaja terkenal dengan hal coba mencoba sesuatu. 
BNN menyebutkan bahwa terdapat 65 jenis Narkotika jenis terbaru yang diatur dalam Undang-Undang Nomor 35 Tahun 2009 Tentang Narkotika. UU tentang Narkotika masih dalam revisian karena masih ada sesuatu hal yang menjadi pertimbangan tentang permasalahan UU Narkotika. Dalam web resmi BNN dijelaskan bahwa laporan akhir tahun BNN menunjukkan terdapat 914 kasus yang telah diungkap dengan 1.335 tersangka sepanjang 2018. Untuk pengguna dirawat dan direhabilitasi milik pemerintah dan masyarakat dengan jumlah 15.263 orang [7].

Perkembangan teknologi yang semakin berkembang dan informasi yang mudah di dapatkan membuat kemudahan diberbagai aspek kehidupan. Kemudahan dalam semuanya dapat menjadikan boomerang bagi sebagian besar manusia yang menggunakan teknologi dan informasi. Di Industri 4.0 ini semakin mudahya mencari sesuatu barang, baik dari luar negeri maupun di dalam negeri. Salah satu akibat negative dari hal ini adalah distribusi dan lolosnya peredaran obatobat terlarang seperti narkoba masuk kedalam kalangan masyarakat umum sampai masuk kedalam sekolah. Para remaja yang masih belum cukup umur dan masih dalam proses mencari jati diri mudah terpengaruh dan menjadi sasaran pemasaran obat-obat terlarang tersebut.

Berdasarkan hasil penelitian Badan Narkotika Nasional yang bekerjasama dengan Pusat Penelitian Kesehatan Universitas Indonesia Tahun 2017 menjelaskan bahwa Survei Nasional Penyalahgunaan Narkoba di Indonesia mencapai $1,77 \%$ atau 3.367 .154 orang yang pernah memakai narkoba dalam setahun terakhir pada usia 10-59. Selain itu juga data menyebutkan bahwa terjadi peningkatan penggunaan kasus psikotopika tahun 2016 sebesar 1.540, pada tahun 2017 meningkat sebanyak 3.652 [8].

Hal ini yang membuktikan bahwa narkoba telah masuk keseluruh lapisan masyarakat dari umur yang muda sampai yang tua dan yang kaya sampai yang miskin. Selain itu juga sasaran narkoba juga mengincar para pelajar yang masih duduk di bangku sekolah. Hal ini juga perlu perhatian dari pihak orang tua, sekolah dan pemerintah karena anak muda merupakan generasi emas untuk Indonesia kelak. Dengan ancaman narkoba yang seperti itu dan ditambah dengan jaman Industri 4.0 semakin mudahnya mendapatkan obat-obatan yang terlarang tersebut. Narkoba memiliki dampak negatif yang sangat luas, baik secara fisik, psikis, ekonomi, sosial, budaya, hankam, dan lainnnya. Bila penyalahgunaan narkoba tidak diantisipasi dengan baik dan secara serius, maka akan rusak bangsa dan negara ini. Oleh karena itu, diperlukan kerja sama yang baik dari seluruh komponen bangsa untuk penanggulangan penyalahgunaan narkoba [9], [10].

Pentingnya wawasan tentang Narkotika sejak dini, pastinya akan memberikan informasi yang lebih awal tentang Narkotika terhadap pelajar-pelajar yang masih dalam fase masa pertumbuhan dan rasa ingin tahu yang lebih [11], [12]. Romli [13] menjelaskan bahwa pengedar Narkotika dan sindikat narkoba dihukum berat namun pelanggaran tidak penah berhenti. Hal ini karena perdagangan saat ini sangat mengutungkan atau survey yang sangat berat. Masyarakat harus cepat tanggap dalam ini. Komunikasi harus dijaga dan dijalin sebaik-baiknya antara masyarakat dengan aparat-aparat pemerintah dalam mengadakan pemberantasan penyalahgunaaan naarkoba. Sehingga peran dari pemerintah, masyarakat, sekolah dan badan yang berangkutan menjadi satu komponen yang harus berkomunikasi untuk permasalahan ini.

\subsection{Latar Belakang Pemilihan Sasaran}

Kota Malang memiliki daya Tarik tersendiri oleh masyarakat yang akan berkunjung ke Malang, karena kota ini terkenal dengan hawanya yang dingin dan sejuk sehingga menjadikan Malang sebagai kota yang dingin. Selain hal itu juga, perkembangan dibidang lain semakin merajalela dan menjadikan Kota Malang semakin terpenuhi diseluruh bidangnya. Kemajuan teknologi dan kebutuhan masyarakat membawa dampak negative dan positif bagi seluruh penduduk yang berada di Kota Malang. Salah satunya adaalah Narkotika. Dalam berita JawaPos.com yang dirilis tanggal 13 Maret 2018, menyatakan bahwa Malang merupakan salah satu tempat sasaran obat-obatan terlarang tersebut, lebih parah lagi bahwa penyalahgunaan Narkoba tersebut dilakukan oleh kalangan pelajar di Kota Malang.

Data yang diperoleh dari Polres Malang Kota selama bulan Januari-Februari 201, memaparkan bahwa ada 36 kasus yang terlibat oleh Narkoba dengan 46 tersangka. Cukup mengejutkan bahwa $60 \%$ tersangka tersebut adalah kalangan pelajar. Hal ini menjadi permasalahan yang serius yang harus segera ditangani oleh pemerintahan Kota Malang. Seperti yang diketahui 
bahwa Malang merupakan salah satu kota pendidikan yang baik di Jawa Timur, hal ini merupakan ancaman terbear karena para pelajar atau remaja bahkan mahasiswa berkumpul di Kota Malang untuk menempuh pendidikan. Pemberian informasi-informasi yang terkait masalah Narkoba juga harus ditangani sejak dini dan tidak boleh terlambat, karena sasaran yang manis untuk pengedar Narkoba adalah disasarkan pada remaja yang masih dalam proses pedewasaan dan mencari jati dirinya, yaitu kalangan Sekolah Menengah Pertama (SMP). SMP di Kota Malang berjumlah banyak, terdiri dari swasta dan negeri yang tersebar di seluruh penjuru Kota Malang.

Salah satu SMP swasta yag berada di Malang adalah SMP Wahid Hasyim. SMP Wahid Hasyim ini terletak di Jl. Mayjen Haryono No. 165 Dinoyo Kecamatan Lowokwaru Kota Malang. Kepala sekolah SMP Wahid Hasyim untuk tahun ini adalah Ibu Sri Pudjiastuti. Siswanya terdiri dari 170 siswa laki-laki dan 121 siswa perempuan. Jumlah total siswa yang berada di SMP Wahid Hasyim sekitar 300 anak dari kelas VII, VIII, dan IX (kemendikbud.go.id) Pemilihan sasaran ini untuk diadakan sosialisasi Narkoba adalah sekolah yang berada ditengah Kota Malang, SMP Wahid Hasyim merupakan salah satu SMP Swasta yang berada di Kota Malang, ketiga karena dekat dengan Universitas Negeri Malang, selain itu sesuai data bahwa di SMP ini jarang ada sosialisasi mengenai narkoba sehingga SMP ini cocok menjadi sasaran untuk dilakukannya Sosialisasi Narkoba. Sasaran untuk sosialisasi ini yaitu seluruh siswa yang berada di SMP Wahid Hasyim mulai dar kelas VII, VIII, dan IX yang berjumlah sekurangnya 300 anak. Rata-rata umur siswa-siswi yang ada disini adala 12-15 tahun sehingga sudah masuk tahap remaja awal. Dalam hal ini siswa-siswi ini perlu adanya pemberian informasi-informasi dan pencegahan sejak dini agar siswa-siswi ini sudah mengetahui informasi tentang Narkoba, dapat menghindari Narkoba dan dampak yang diperoleh jika menyalahgunakan narkoba, sehingga sejak remaja awal siswa sudah mendapatkan informasi terkait hal ini.

\subsection{Jalannya Sosialisasi Gerakan Siswa Anti Narkoba}

Kegiatan yang bertema Kontrol Diri Sebagai Tameng Menghadapi Globalisasi dan Bahawa Narkoba Pada Remaja di Era 4.0 ini dilaksanakan selama satu hari pada tanggal 29 Maret 2019 mulai pukul 07.00-09.35 WIB. Peserta kegatan ini adalah siswa kelas VII, VIII, dan IX. Rencana dari kelompok, sasaran peserta yaitu hanya satu atau dua kelas saja, namun begitu senang dan antusias dari pihak sekolah termasuk kepala sekolah memberikan kesempatan untuk dapat memberikan sosialisas seluruh siswa di SMP Wahid Hayim dengan peserta sekitar 300 siswa bak laki-laki atau perempuan, begitu antusias siswa untuk kegiatan ini. Kegiatan GESWANA ini dibagi menjadi beberapa sesi.

\section{Sesi Pertama : Video}

Sosialisasi ini dimulai pada pukul 07.00 WIB dibuka dengan menyanyikan lagu Indonesia Raya dan didampingi oleh 2 guru Pendidikan Agama Islam (PAI) karena tempat sosialsasi yaitu berada di Aula Mushola SMP Wahid Hasyim. Sekitar 300 anak menjadi peserta. Sedangkan untuk pematerinya mengambil salah satu anggota dari kelompok dan 2 dari Unit Kegatan Mahasiswa (UKM) GERMAN UM. Yang lainnya bertugas sebaga dokumentasi, MC, dan operator. Sosialisasi ini dibuka dengan ditayangkan sebuah video yang berdurasi 5 menit yang menceritakan tentang dunia nyata dan dunia gadjed dalam era industry 4.0 ini. Video tersebut diputar untuk memberikan stimulus pada siswa sebelum menginjak pada pokok bahasan sosialsasi kali ini.

Untuk persiapan, materi disajikan dalam bentuk Power Point, sehingga pemateri membutuhkan seperangkat LCD sebagai alat bantu untuk memproyeksikan pada layar. Selain itu, karena banyaknya peserta sekitar 300 peserta, maka juga membutuhkan mic dan pengeras suara agar semuanya juga terdengar pada saat penjelasan. Semua peralatan yang dibutuhkan sudah disediakan oleh sekolah. Peserta pun sudah terkondisikan di Aula Mushola pada saat kelompok datang, hal ini karena sekolah menerapkan sholat dhuha di masjid sehingga semua sudah terkendalikan. Video yang ditampilakn yaitu tentang remaja. Lebih tepatnya adalah video tentang remaja yang bermain gadjed dan media sosial. Video ini berdurasi sekitar 5 menit. Hal yang didapatkan dari video ini adalah realita media sosial atau dunia maya tidak sesuai dengan kehidupan yang nyata. Semua tampak berbeda dan perlu adanya keseimbangan antara keduanya.

Sesi Kedua : Sosialisasi materi Globalisasi 
Sesi kedua dari kegiatan ini adalah sosialisasi pertama dan pematerinya adalah dari kelompok. Kelompok berkesempatan untuk membawakan materi tentang "globalisasi dan industry era 4.0" Hal yang dilakukan pertama adalah peralihan kordinasi ke pemateri dan pembukaan oleh pemateri. Pembahasan awal dijelaskan tentang globalisasi. Materi disampaikan menggunakan power point, untung saja semua peralatan yang dibutuhkan sudah tersedia.

Materi awal yang disampaikan adalah gambaran umum tentang globalisasi, pemateri menjelaskan apa yang dimaksud dengan globalisasi serta contoh nyata bentuk globalisasi dalam kehidupan remaja masa kini. Selain menjelaskan tentang pengertian dan betuk globalisasi, pemateri juga menjelaskan dampak dari adanya globalisasi dalam ranah pendidikan, agar peserta sosialisasi lebih dapat memahami. Selama pemaparan materi, diselingi juga tanya jawab. Materi terakhir yang diberikan dalam sesi kedua ini adalah tentang era 4.0. Materi ini berkaitan dengan pemanfaatan atau penggunaan internet yang begitu menjalar dalam kehidupan sehari-hari, bahkan bukan hanya dikalangan orang dewasa, hampir semua lapisan masyarakat sudah mengenal dan menggunakan internet. Pemateri juga menjelaskan bagaimana pendidikan di era 4.0 yang sedang berlangsung saat ini, apa saja kekurangan dan kelebihannya seta bagaimana mengambil sikap yang tepat menghadapi era 4.0.

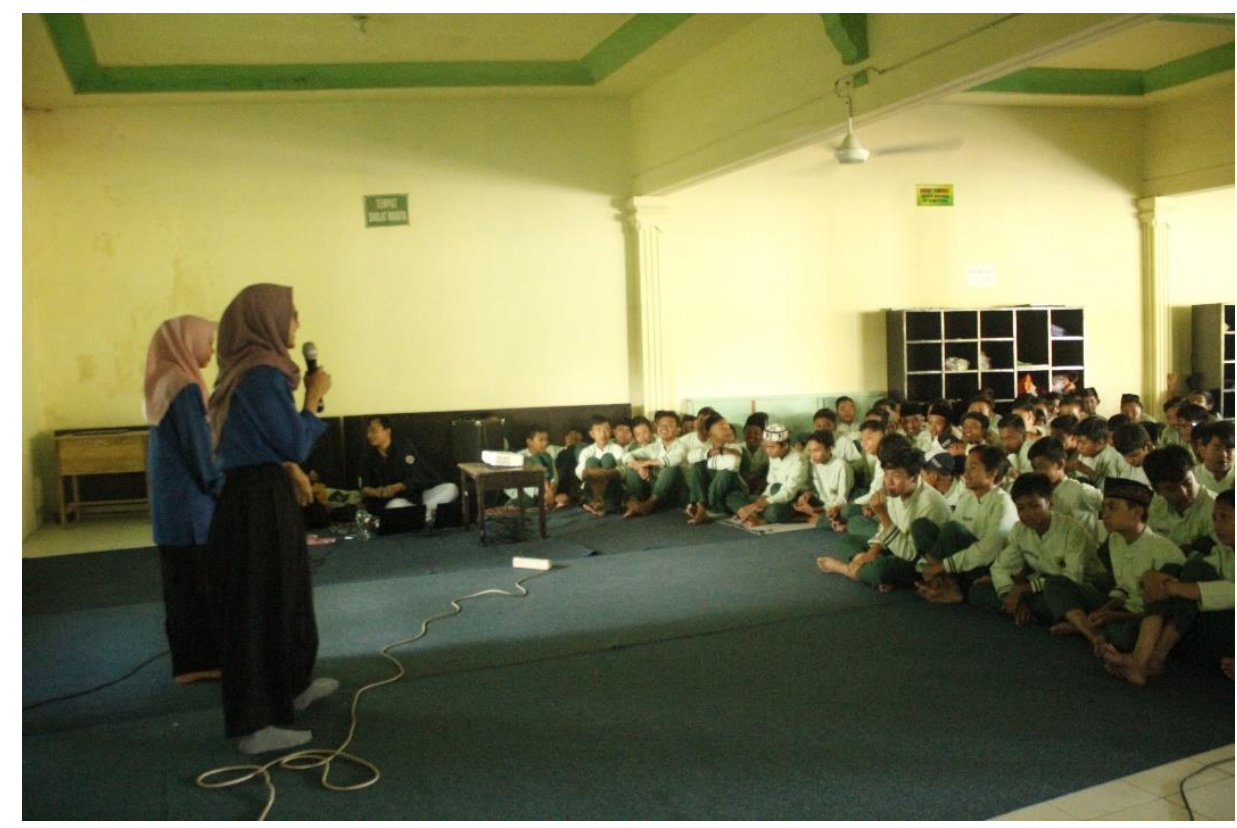

Foto 1 : Sosialisasi materi globalisasi (Dokumentasi Pribadi)

Setelah pemaparan materi selesai, peserta sosialisasi diajak untuk menonton film pendek tentang bagaimana internet dan handphone menjadi hal yang tidak dapat dilepaskan dari manusia. Setelah penayangan film tersebut, diberi kesempatan kepada peserta didik untuk menyampaikan kesimpulan atau makna yang dapat diambil dari penayangan film tersebut. Peserta yang berani menyampaikan pendapatnya diberi hadiah oleh panitia penyelenggara sosialisasi. Dari sesi kedua in, banyak sekali respon yang baik yang muncul dari peserta sosialisasi.

\section{Sesi Ketiga : Sosialisasi Narkoba GERMAN UM}

Sesi ketiga dari kegiatan ini adalah sosialisasi kedua dan pematerinya adalah dari UKM GERMAN UM. Pemateri kedua yaitu membawakan tentang "Narkoba". Dalam materi tersebut terdapat 2 mahasiswa dari UK GERMAN yang menjelaskan secara mendetail mengenai narkoba, baik dari jenis-jenisnya, dampak dan penemuan-penemuan terbaru jenis narkba. 


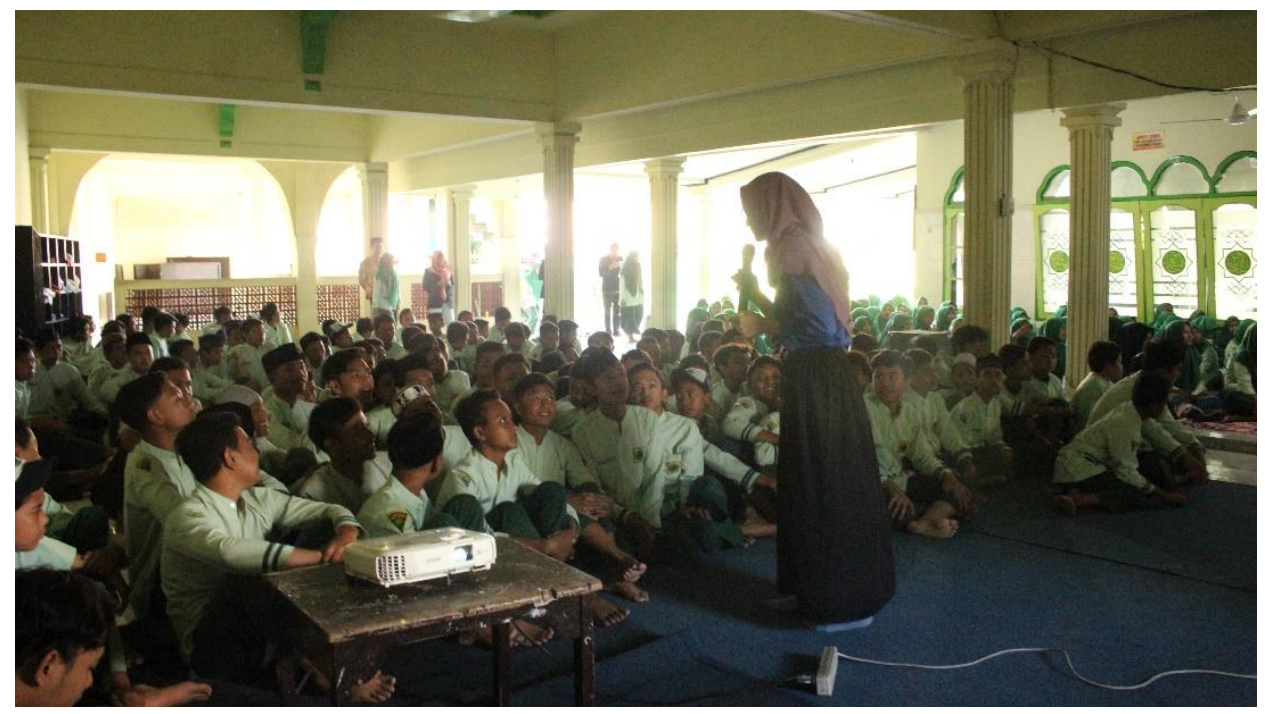

Foto : Kegiatan Sosialisasi bahaya narkoba (Dokumentasi pribadi)

Dalam materi tersebut, materi awal dijelaskan tentang Narkoba baik dari jenis-jenisnya. Materi awal yang disampaikan menggunakan PPT dan dengan metode ceramah dalam menyampaikan ke anak-anaknya. Dan diberikan sedikit pertanyaan untuk memancing para audients. Antusias siswa yang membuat semakin menarik pembahasan kali ini. Di mater selanjutnya juga dijelaskan mengenai zat apa saja yang masuk dalam kandungan satu batang rokok. Di materi ini dijelaskan spesifik jika orang menjadi perokok pasif dan aktif. Selain itu dampak yang timbul di tubuh para perokok juga dijelaskan secara detail. Tidak lupa bahwa dimateri ini juga diselingi tentang materi alcohol dan mirass.

\section{Sesi Keempat : Refleksi dan Evaluasi Kegiatan}

Setelah adanya kegiatan sosialisasi dari video, materi 1 dan materi 2 maka disesi akhir siswa diajak untuk melakukan evaluasi dan refleksi. Kegiatan evaluasi ini diisi dengan sesi tanya jawab oleh pemateri dan peserta. Dalam kegiatan ini yang paling akhir yaitu adanya refleksi dan evaluasi kegiatan. Refleksi ini yaitu siswa diajak untuk berfikir mengenai apa yang didapatkan untuk hari ini dan ditunjuk secara acak. Selain itu juga adanya pertanyaan-pertanyaan jika siswa ada materi yang kurang paham bisa ditanyakan. Dalam sesi ini dibatasi 5 orang siswa yang ini memberikan pendapatnya.

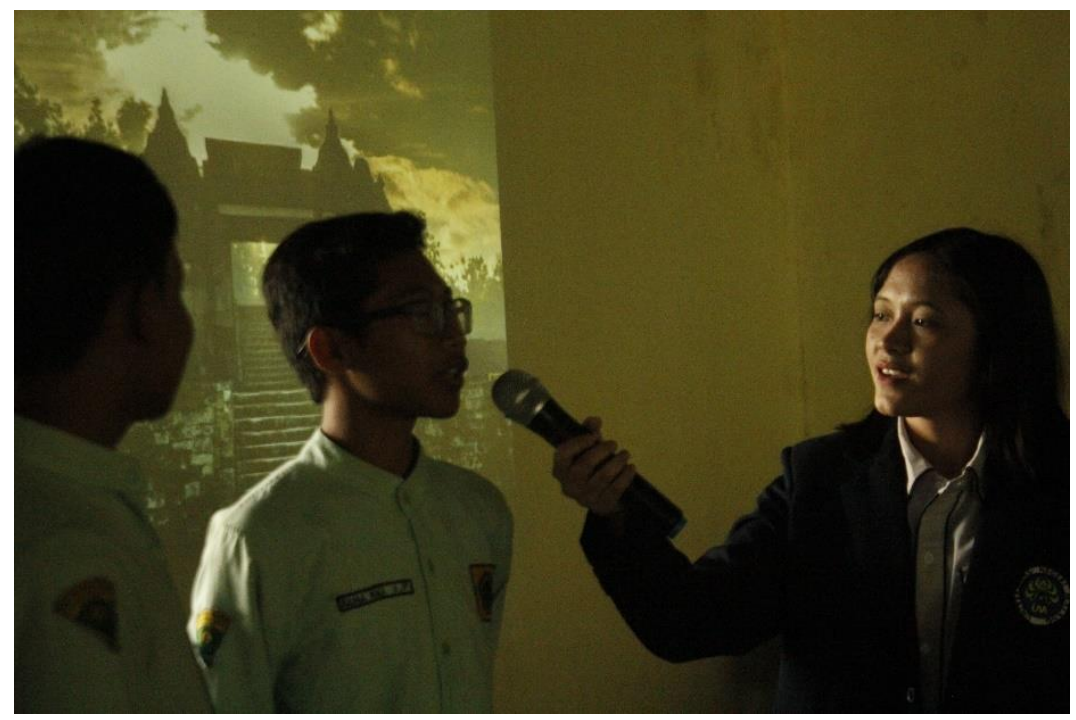

Foto 3. Siswa memberikan pendapat dalam evaluasi (Dok. Pribadi) 


\section{Sesi Kelima : Pembagian Hadiah, Snack dan Persiapan Pulang}

Setelah adanya kegiatan sesi tanya jawab, maka sesi selanjutnya pembagian hadiah, snack dan persiapan pulang. Sesi ini merupakan sesi akhir dalam kegiatan acara yaitu pembagian hadiah bagi siswa-siswa yang sudah mau memberikan pendapatnya dan mau ke depan dalam acara kuis dan ice breaking. Masing-masing siswa diberi satu hadiah dan satu pin, serta stiker untuk siswa nya. Dan di akhiri dengan foto bersama.

Di sesi selanjutnya yaitu pembagian sncak oleh panitia dan guru-guru sekolah yang juga membantu dalam kegiatan tersebut. Karena juga siswa yang terlalu banyak dan panitia yang hanya terbatas, saat pembagian snack disendirikan cewek dan khusus cowok, serta seluruh siswa juga mendapatkan stiker gratis dari panitia, dan dilanjutkan dengan foto panitia. Sebelum pulang, panitia mewawancari salah satu dari siswa untuk berkomentar tentang kegiatan ini, lalu dilanjutkan dengan berpamitan ke pihak sekolah, dimana panitia bertemu dengan Ibu Kepala Sekolah SMP Wahid Hasyim untuk mengucapkan terima kasih. Setelah itu kelompok pun kembali ke tempat masing-masing.

\subsection{Capaian Yang Didapat}

Untuk kegiatan dimulai pukul 07.30 s/d 09.00 WIB yang bertepatan di Aula Masjid SMP Wahid Hasyim Kota Malang. Kegiatan tersebut ada beberapa sesi mulai dari sesi materi, sesi tanya jawab, pemutaran video, dll. Dalam sesi materi ada materi yang disampaikan dari UKM German secara langsung mengenai Ke-Napzaan dan materi dari kelompok yaitu globalisasi di era digital ini. Selain itu juga semakin menarik dengan diputarkan video sebagai stimulus agar siswa mampu mengetahui makna atau refleksi diblaik video tersebut dan dilanjutkan dengan sesi tanya jawab. Kendala dalam hal pencarian sekolah yang awalnya mau di jenjang SMA, namun dengan adanya kesulitan dalam hal administrasi maka kelompok mencari sekolah yang mudah dalam administrasi dan dengan sekolah yang dirasa cocok untuk kegiatan sosialisasi ini. Nama kegiatan itu sendiri bernama Gerakan Siswa Anti Narkoba (GESWANA). Selain itu juga kordinasi kelompok yang sulit karena terbenturnya jadwal kuliah karena jadwal kuliah yang berbeda.

Dalam kegiata ini yang paling terpenting adalah pemberian informasi sejak dini dan penanggulangan sejak dini mengenai jenis narkoba, alkohol dan sejenisnya untuk para pelajar. Bahwa sekarang para pengedar narkoba juga mengincar para pelajar, karena notabene para pelajar SMP masih dalam proses pendewasaan dan labil-labilnya. Pemberian bekal tersebut semoga bermanfaat buat siswa-siswi dari SMP Wahid Hayim Kota Malang dalam kegiatan GESWANA dengan tema "Kontrol Diri Sebagai Tameng Menghadapi Globalisasi dan Bahaya Narkoba Pada Remaja Di Era 4.0 di SMP Wahid Hasyim Kota Malang yaitu tindakan kecil yang harus digencarkan mulai sekarang untuk pemberian informasi sejak dini tentang bahaya narkoba. Capaian yang didapat dari kegiatan ini dapat dilihat dari dua hal, yang pertama adalah antusias siswa dalam mengikuti kegiatan ini. Selama proses pengamatan yang dilakukan oleh tim selama kegiatan berlangsung menunjukkan bahwa siswa sangat antusias dan bersemangat. Hal ini dapat dilihat dari jumlah mereka secara kuantitas dari perserta yang ditetapkan dari semula tidak ada yang ijin meninggalkan kegiatan hingga selesai. Selain itu juga partisipasi aktif mereka dengan intensitas pengajuan pertanyaan terkait materi yang disampaiakan. Pengukuran capaian yang berikutnya adalah evaluasi kualitatif yang dilakukan setelah acara selesai. Dilakukan wawancara dengan beberapa peserta, dan dari jawaban mereka menyatakan bahwa acara ini memberikan manfaat bagi mereka. Informasi baru mengenai nerkoba yang didapatkan oleh para peserta sangat bermanfaat untuk mencegah terjadinya penyimpangan dalam penyalahgunaan narkoba.

\section{KESIMPULAN}

Kesimpulan dari artikel ini diuraikan secara rinci dalam beberapa point di bawah ini :

1. Malang merupakan salah satu kota besar dan juga menjadi salah satu kota pelajar di Jawa Timur, sehingga mengakibatkan banyaknya orang-orang dari luar untuk berpindah ke Malang khususnya bekerja dan mencari ilmu. Migrasi dari kalangan tersebut memungkinkan adanya tindak pelanggaran, salah satunya persebaran Narkoba yang telah banyak beredar dari berbagai 
latar belakang pendatang dan dikhawatirkan untuk disalah gunakan. Hal demikian ditambah dengan perkembangan tehnologi pada saat ini, sehingga memudahkan seseorang khususnya pelajar dalam mengakses apapun terutama dalam hal Narkoba. Hal inilah yang melatarbelakangi dalam upaya melakukan sosialisasi kepada para pelajar sebagai langkah untuk membentengi diri terhadap peredaran Narkoba. Sosialisasi khususnya ditujukan kepada siswa-siswi tingkat SMP karena dianggap banyak pelajar dari kalangan SMP di Malang yang telah menjadi korban peredaran Narkoba. Sosialisai ini diharapkan dapat memberikan gambaran akan bahayanya penyalahgunaan Narkoba dan juga memberikan pengetahuan yang lebih terkait Narkoba.

2. Kegiatanh pengabdian berupa sosialisasi narkoba berlangsung dengan baik dan antusias yang tinggi dari peserta selama kegiatan berlangsung. Hasil dari kegiatan ini adalah tumbuhnya kesadaran bagi para peserta kegiatan mengenai bahaya penggunaan narkoba. Informasi yang disampaiakan melalui kegiatan ini menjadi wawasan yang membuat peserta semakin sadar dan waspada bahwa penggunaan narkoba dengan berbagai bentuknya sangat berbahaya dan merugikan.

\section{SARAN}

Untuk penelitian dan pengabdian lanjutan dari pengabdian praksisi sosial ini disarankan dalam bentuk implikasi dari pencegahan narkoba di sekolah-sekolah. Tidak hanya sebatas sosialisasi saja melainkan sudah ada aksi nyata sebagai tindak lanjut. Kegitan pengabdian semacam ini sangat efektif untuk memberikan pengetahuan mengenai bahaya narkoba, oleh karena itu kedepanya terus dilakukan dengan subjek dan objek yang lainya.

\section{UCAPAN TERIMA KASIH}

Penulis mengucapkan terima kasih kepada Jurusan Sejarah ,Fakultas Ilmu Sosial, Universitas NEGERI Malang yang telah memberikan dukungan bagi terlaksananya kegiatan ini. Terimakasih kami ucapkan juga untuk pihak sekolah sasaran yang memfasiltasi tim dalam melakukan kegiatan ini.

\section{DAFTAR PUSTAKA}

[1] https://malangkota.go.id, "Geografis," Pemerintah Kota Malang. .

[2] www.jawapos.com, "Miris, 60 Persen Pengguna Narkoba di Malang adalah Pelajar," 2018. [Online]. Available: https://www.jawapos.com/jpg-today/13/03/2018/miris-60-persenpengguna-narkoba-di-malang-adalah-pelajar/. [Accessed: 02-Oct-2019].

[3] O. H. K. P. RI, "Menko Polhukam Tegaskan Narkoba Ancaman Terbesar Bangsa Indonesia," Kemenko Polhukam RI, 2019. [Online]. Available: https://polkam.go.id/menko-polhukamtegaskan-narkoba-ancaman-terbesar-bangsa-indonesia/. [Accessed: 02-Oct-2019].

[4] W. D. Sulistyo, "MENGGUGAH SENSITIVITAS SOSIAL MAHASISWA MELALUI IMPLEMENTASI PRAKSIS SOSIAL," Jurnal Sosiologi Pendidikan Humanis, vol. 4, no. 1, pp. 38-46, Aug. 2019.

[5] W. D. Sulistyo et al., "Sosialisasi dan Implementasi Kegiatan Nata Raga" Encourage Healthy Life Style di SMP Negeri 2 Pakisaji," Jurnal Abdimas BSI: Jurnal Pengabdian Kepada Masyarakat, vol. 2, no. 2, pp. 340-349, Aug. 2019.

[6] https://beritagar.id, "Data Badan Narkotika Nasional (BNN) yang terbaru menjelaskan bahwa dari sekian pecandu narkoba yang ada di Indonesia, sekitar $24 \%$ merupakan para pelajar yang keblinger dan lepas kendali hingga menjadi pecandu - Google Search,” 2018. [Online]. Available:

https://www.google.com/search?q=Data+Badan+Narkotika+Nasional+(BNN)+yang+terbaru +menjelaskan+bahwa+dari+sekian+pecandu+narkoba+yang+ada+di+Indonesia\%2C+sekitar $+24 \% 25+$ merupakan+para+pelajar+yang+keblinger+dan+lepas+kendali+hingga+menjadi+pe 
candu\&rlz=1C1CHBF_enID843ID843\&oq=Data+Badan+Narkotika+Nasional+(BNN)+yang +terbaru+menjelaskan+bahwa+dari+sekian+pecandu+narkoba+yang+ada+di+Indonesia\%2C +sekitar+24\% 25+merupakan+para+pelajar+yang+keblinger+dan+lepas+kendali+hingga+me njadi+pecandu\&aqs=chrome..69i57.986j0j4\&sourceid=chrome\&ie=UTF-8. [Accessed: 02Oct-2019].

[7] mediaindonesia com developer, "BNN Ungkap 914 Kasus Narkotika dengan 1.355 Tersangka Sepanjang 2018," 20-Dec-2018. [Online]. Available: https://mediaindonesia.com/read/detail/205488-bnn-ungkap-914-kasus-narkotika-dengan1355-tersangka-sepanjang-2018. [Accessed: 02-Oct-2019].

[8] O. PUSLITDATIN, "Penggunaan Narkotika di Kalangan Remaja Meningkat," Badan Narkotika Nasional RI, 12-Aug-2019. [Online]. Available: https://bnn.go.id/penggunaannarkotika-kalangan-remaja-meningkat/. [Accessed: 02-Oct-2019].

[9] K. Kartono, "Patologi sosial jilid 1," Jakarta: PT Rajagrafindo Persada, 2011.

[10] P. Burlian, Patologi Sosial (full text). Bumi Aksara, 2016.

[11] R. E. Kusmaryani, Mengenal Bahaya Narkoba bagi Remaja. 2009.

[12] A. Sukron and W. Warsono, "Pencegahan Penyalahgunaan Narkoba Melalui Kader Penyuluh Anti Narkoba Unit Kegiatan Mahasiswa Peduli Penyalahgunaan NAPZA Universitas Airlangga Surabaya," Kajian Moral dan Kewarganegaraan, vol. 3, no. 2, pp. 927-940, 2014.

[13] R. Atmasasmita and S. H. H Bambang Poernomo, "Tindak pidana narkotika transnasional dalam sistem hukum pidana Indonesia," PhD Thesis, [Yogyakarta]: Universitas Gadjah Mada, 1996. 